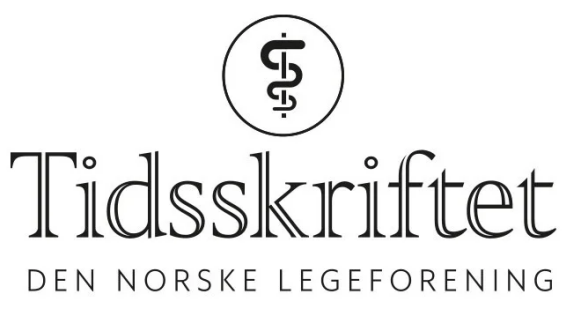

\title{
Historien om pasienttransport med fly
}

TIDLIGERE I TIDSSKRIFTET

\section{JULIE DIDRIKSEN}

julie.didriksen@tidsskriftet.no Tidsskriftet

I Tidsskriftets utgave 9/1925 ble en fransk artikkel sammenfattet i spalten Oversigter, referater og praktiske notiser. Her kunne vi lese om de første pasientene som ble fraktet med fly. Ikke overraskende var det snakk om soldater i krigsrammede områder. Skribenten hadde stor tro på at fly burde tas mer aktivt i bruk for å frakte pasienter (Tidsskr Nor Lægeforen 1925; 45: 461).

P. Defosses: Flyvemaskiner til transport av saarede. 


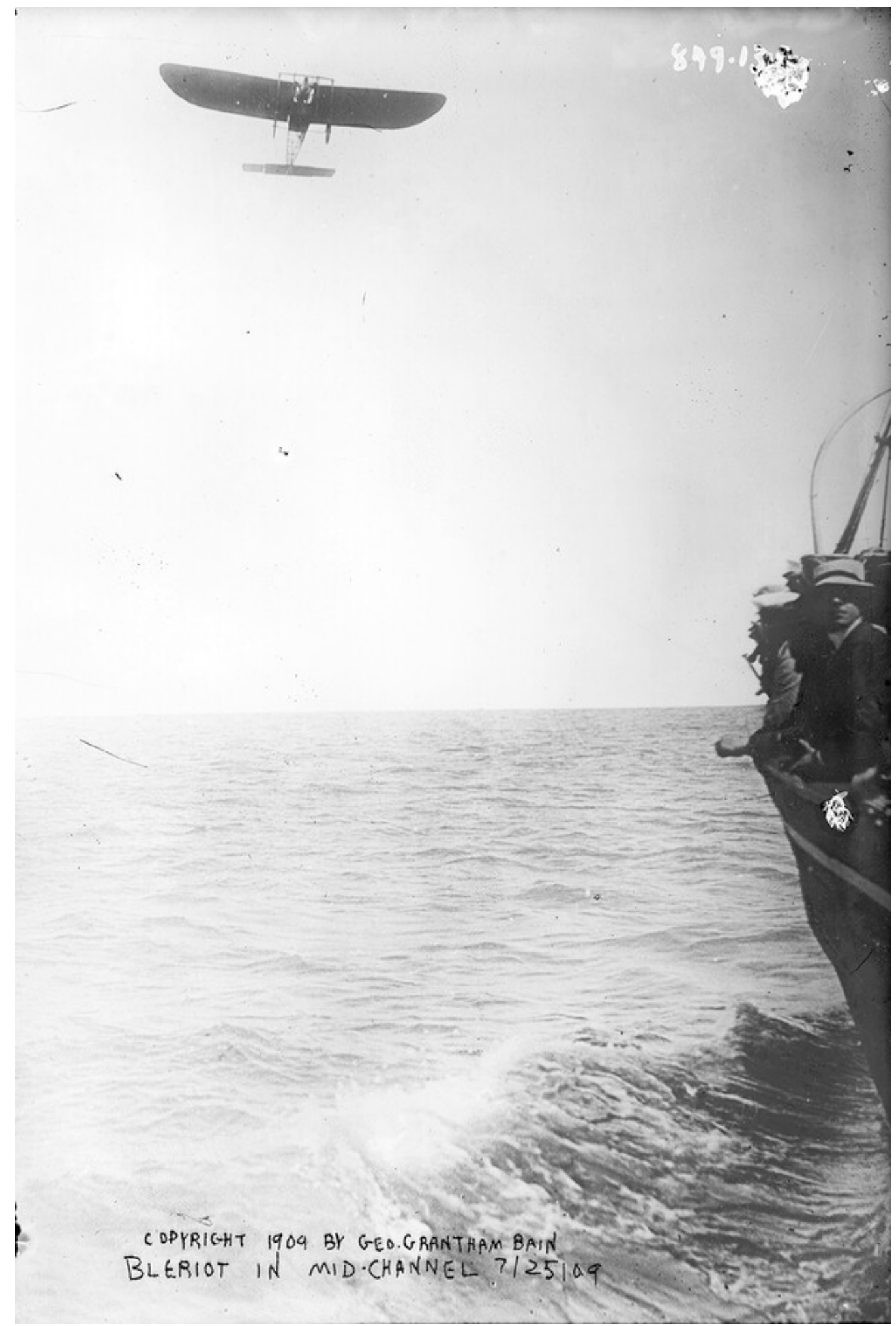

Den franske flyveren Louis Blériot (1872-1936) flyr over Den engelske kanal, 25. juli 1909. Illustrasjon: Public Domain Mark Da Blériot 1910 (sic) gjorde det dumdristige forsøk at flyve over kanalen, nævnte den hollandske medicinaldirekt $ø$ r De Mooy, at man i fremtiden muligens vilde kunne anvende flyvemaskiner til transport av saarede.

"Litet ante man den gang, at de paafølgende aar skulde bringe en utvikling av flyveteknikken, som ncermest maa betegnes som fantastisk» 
Litet ante man den gang, at de paafølgende aar skulde bringe en utvikling av flyveteknikken, som nærmest maa betegnes som fantastisk selv for dem, som med egne øine har sett resultaterne derav, vor tids vidundere av driftssikre luftomnibusser. Allerede tidlig under verdenskrigen blev flyvemaskinen tat til hjelp ved transport av de saarede. Den første kjendte syketransport blev foretat paa krigsjagere under serbernes retræt av kaptein Dangelzer og løitnant Paulhan, som tok med sig et dusin av sine haardtsaarede kamerater, som ikke kunde transporteres paa anden maate. I 1917 fik sanitetsmajor Chassain konstruert den første flyvemaskine til syketransport, en type som blev brukt til 1921, da der blev bygget større og mere komfortable sanitetsflyvemaskiner.

Værd at erindre er oberst Lenains daad, da han 1920, som flyvernes chef i Levanten, lot jagerne desarmere for at opsøke de efterlatte saarede og syke, hvorav de, som trængte det, pr. flyvemaskin blev transportert til hospitalerne. Nogen maaneder senere organiserte han det enda mere farefulde tolk, da han efter kampene ved Euphrat lot sine flyvere bringe over 50 saarede optil $350 \mathrm{~km}$. fra flyvestationen til fjernere sanitetsanstalter.

\section{"Vard at erindre er oberst Lenains daad, da han 1920, som flyvernes chef $i$ Levanten, lot jagerne desarmere for at opsøke de efterlatte saarede og syke»}

I Marokko tok oberst Cheutin i stor utstrækning flyvemaskinerne til hjelp ved transport av de haardtsaarede, som ikke kunde transporteres paa anden maate. Fra 1ste januar til 1ste november 1923 blev ikke mindre end 1050 haardtsaarede transportert fra Marokko pr. flyvemaskin. I alt blev der fra Marokko og fra Levanten transportert hjem til Frankrike 2800 haardtsaarede, hvorav man vel kan regne, at $2 / 3$ uten den skaansomme og hurtige transport vilde været redningsløst fortapt. De saarede anbringes 2 liggende og 1 sittende i en komfortabel, elektrisk opvarmet lugar, hvor de kan faa tilsyn og pleie under transporten. Ved en stor utstilling av sanitetsmateriel (fransk og amerikansk) nylig i San. Antonio i Texas utstilledes ogsaa en del moderne sanitetsflyvemaskiner, hvorav de franske stod fuldt paa høide med de amerikanske.

Tilsut foreslaar forf., at der rundt om i Frankrike oprettes stationer med sanitetsflyvemaskiner færdige til at tages i bruk ved større ulykkestilfælder, for at syke og saarede snarest fra distrikterne kan bringes paa en skaansom maate til kyndig behandling $\mathrm{i}$ dertil skikkede hospitaler.

(Presse Médicale, nr.100, 1924.)

Publisert: 28. februar 2022. Tidsskr Nor Legeforen. DOI: 10.4045/tidsskr.21.0868

(C) Tidsskrift for Den norske legeforening 2023. Lastet ned fra tidsskriftet.no 26. april 2023. 